
\title{
28 Research Square \\ Functionalization of Two-Dimensional Coordination Polymer in Small Organic Matters Removal from Organic Wastewater
}

Billy Oktora Abdilah Fauzi ( $\square$ billy.oktora.a.fauzi.18@shizuoka.ac.jp )

Shizuoka University https://orcid.org/0000-0003-0269-0570

Mitsuru Kondo

Shizuoka University

Mohamed I. Elzagheid

Jubail Industrial College

Lydia Rhyman

University of Mauritius

Ponnadurai Ramasami

University of Mauritius

\section{Research Article}

Keywords: bis-imidazole, two-dimensional coordination polymer, small organic matter removal

Posted Date: January 21st, 2022

DOI: https://doi.org/10.21203/rs.3.rs-1277764/v1

License: (c) (i) This work is licensed under a Creative Commons Attribution 4.0 International License.

Read Full License

Version of Record: A version of this preprint was published at Journal of Inorganic and Organometallic Polymers and Materials on July 19th, 2022. See the published version at https://doi.org/10.1007/s10904022-02435-5. 


\section{Abstract}

Multicobalt(II) two-dimensional layer coordination polymer $\left\{\left[\mathrm{Co}(\text { bitbu-OMe })_{2}(\mathrm{NCS})_{2}\right] \cdot 2 \mathrm{MeOH}\right\}_{\mathrm{n}}(1)$ was synthesized using a bis-imidazole ligand having a steric hindrance, tert-butyl, and one methoxy group expressed by bitbu-OMe (bitbu-OMe = 1,1'-[(5-tert-butyl-2-methoxybenzene-1,3-diyl)dimethanediyl]bis $(1 \mathrm{H}$ imidazole). Since there are two methanol molecules trapped inside each void within 1 , the investigation of small organic matters removal from organic wastewater was conducted in order to reveal its ability in the purification process. The research findings indicate that 1 has the ability to capture methanol, acetone, acetonitrile, and tetrahydrofuran in organic wastewater with removal ratios of $29.17 \%, 63.22 \%$, $42.77 \%$, and $21.24 \%$, respectively.

\section{Introduction}

The issue to have clean water has always been a topic of importance [1] and access to clean water is a major component to Sustainable Development Goal 6 [2]. Water pollution occurs because of a large number of waste discharges [3] from various sources [4-7]. One of the issues that arises in research activities from chemical laboratories is the production of organic wastewater [8-11]. Generally, organic wastewater from a chemical laboratory consists of a mixture of used water and waste organic solvents [12]. Various efforts have been being established to recycle organic wastewater to produce clean water, such as using zeolite as a purification agent to absorb organic matter dissolved in organic wastewater by utilizing its microporous [13-19].

In addition to using zeolite as an organic matter adsorbent in organic wastewater treatment, the use of materials having voids such as two-dimensional coordination polymers (CPs) [20] for organic wastewater treatment has become interesting to study due to the unlimited variation of metal ions and bridging ligands involved to form novel coordination polymers [21]. These have generated special interests because of the metal ions and the ligands used and thus, these substances should not have side effects on the human body and the environment. Therefore, the development of two-dimensional coordination polymers in the absorption process of small molecules $[22,23]$ as a purification agent has become useful in the process of organic wastewater purification. We reported on the synthesis and characterisation of a two-dimensional layer coordination polymer $\left\{\left[\mathrm{Co}(\text { bitbu-OMe })_{2}(\mathrm{NCS})_{2}\right] \cdot 2 \mathrm{MeOH}\right\}_{\mathrm{n}}$ synthesized from $\mathrm{Co}(\mathrm{SCN})_{2}$ and bis-imidazole ligand having a steric hindrance tert-butyl, and a methoxy group called bitbuOMe where this polymer, Fig. 1, has methanol molecules encapsulated within its voids [24].

In view of the above and in continuation with our research programme to study the purification of water [25-30], herein, we report the functionalization of $\left\{\left[\mathrm{Co}(\text { bitbu-OMe })_{2}(\mathrm{NCS})_{2}\right] \cdot 2 \mathrm{MeOH}\right\}_{\mathrm{n}}(1)$, its action in the purification of organic wastewater in the removal of small organic molecules such as methanol, acetone, acetonitrile, and THF through the utilization of its voids.

\section{Material And Methods}


All solvents and reagents were available commercially and used without further purification. Powder Xray diffraction (PXRD) measurement was conducted using the Rigaku Smart Lab. Nuclear magnetic resonance (NMR) measurement was carried out using JEOL ECA-600 Spectrometer. Thermogravimetrydifferential thermal analysis (TG-DTA) was performed using Rigaku TG 8121.

The process of small organic molecules removal in organic wastewater by using 1 began with the identification of optimum temperature for desolvation process of 1's voids through the thermogravimetric analysis (TG analysis). Thus, the process of removing methanol molecules and the stability of the structure of 1 before and after desolvation process through heating was carried out by comparing the simulated PXRD patterns of 1 with and without methanol molecules and the observed PXRD patterns of 1 before and after desolvation process.

The organic wastewater representation was prepared by adding 2,2-dimethylpropan-1-ol (neopentyl alcohol, NPA) $(0.018 \mathrm{~g}, 0.200 \mathrm{mmol})$ to $20 \mathrm{~mL}$ of $\mathrm{D}_{2} \mathrm{O}$. The NPA solution was separated into four vials ( 5 $\mathrm{mL}$ of solution for each vial). $0.400 \mathrm{mmol}$ of each small organic molecule $\left(\mathrm{MeOH}, \mathrm{Me}_{2} \mathrm{CO}, \mathrm{MeCN}\right.$, and THF) was added to each vial. $0.500 \mathrm{~mL}$ of each small organic matter solution was added into the NMR tube ${ }^{1} \mathrm{H}$ NMR for analysis (Fig. 2).

The capture of small organic molecules using desolvated 1 was conducted by mixing the powder of desolvated 1 powder $(0.040 \mathrm{~g}, 0.05 \mathrm{mmol})$ with four small organic molecule solutions. The mixtures of desolvated 1 powder and small organic molecule solutions were stirred for one hour at room temperature. The mixtures were filtered using a filter attached to the syringe. $0.500 \mathrm{~mL}$ of each solution was added into the NMR tube for ${ }^{1} \mathrm{H}$ NMR analysis.

The equation used for small organic molecules removal ratio was derived from the relative quantitative NMR (qNMR) [31], equation (1),

$\frac{n_{x}}{n_{y}}=\frac{I_{x}}{I_{y}} \frac{N_{x}}{N_{y}}(1)$

where $n_{x} / n_{y}, I_{x}, I_{y}, N_{x}$ and $N_{y}$ are molar ratio of two compounds, the integrated signal area of compound $x$, the integrated signal area of compound $y$, the number nuclei of compound $x$, and the number nuclei of compound y, respectively. Equation (1) was used to calculate the molarity of organic molecules after removal treatment $\left(n_{a}\right)$ from molarity of organic molecules before removal treatment $\left(n_{b}\right)$, and by assuming the molarity of standard compound, the number nuclei of standard compound, the number nuclei of organic molecules before and after treatment to remain the same. The molar ratio of organic molecules before and after removal treatment was calculated using the equation (2).

$\frac{n_{b}}{n_{a}}=\frac{I_{b}}{I_{a}}(2)$

The percentage of organic molecules removal was calculated using the equation (3) 
Percentage of organic molecules removal $=\frac{\left(I_{b}-I_{a}\right)}{I_{b}} \times 100 \%$ (3)

where $\mathrm{I}_{\mathrm{b}}$ and $\mathrm{I}_{\mathrm{a}}$ are the integrated signal area of organic molecules before and after removal treatment, respectively.

\section{Result And Discussion}

\subsection{Thermogravimetric analysis result}

The percentage by weight of methanol contained in 1 was calculated to be $7.23 \%$. The result of thermogravimetric analysis exhibits a rapid decrease in mass of 1 up to $7.21 \%$ at $42.8^{\circ} \mathrm{C}$ and a slow decrease in mass of 1 below $250^{\circ} \mathrm{C}$ (Figure 3). It can be concluded that all methanol molecules were removed below $45^{\circ} \mathrm{C}$, and the structure of 1 remains stable under $45^{\circ} \mathrm{C}$.

\subsection{PXRD result}

The simulated PXRD pattern is provided as Figure 4, the presence of one peak in the range of $7^{\circ}$ to $8^{\circ}$ in Figure 4 reveals that there are no methanol molecule guests in the voids formed in 1 . The presence of one peak in the range of $7^{\circ}$ to $8^{\circ}$ in Figure 4 confirms that methanol molecules have successfully been removed after heating process below $45^{\circ} \mathrm{C}$. It can be concluded that the voids are completely empty under $45^{\circ} \mathrm{C}$.

\subsection{Small organic matter removal in organic wastewater using 1}

The study of encapsulating small organic molecules in organic wastewater using 1 was conducted by calculating the ratio of the changes in the concentration of organic molecule and was interpreted from the changes in the integrated signal area of small organic molecules obtained from the ${ }^{1} \mathrm{H}$ NMR measurement. Neopentyl alcohol was used as a standard to calculate the removal ratio of organic molecule in the organic wastewater. Neopentyl alcohol was used due to its size which is relatively larger than the size of void within 1. The van der Waals volume of neopentyl alcohol is $104.2 \AA^{3}$ considering the van der Waals modeling with a $100 \%$ radius relativity [32b]. Therefore, the neopentyl alcohol was not captured by 1 .

${ }^{1} \mathrm{H}$ NMR results, Fig. 5, suggest that desolvated 1 powder has the ability to capture methanol, acetone, acetonitrile, and tetrahydrofuran with the removal ratios of $29.17 \%, 63.22 \%, 42.77 \%$, and $21.24 \%$, respectively. Interestingly, 1 has an ability to capture acetone better than other organic molecules even though acetone has a larger size than methanol and acetonitrile. The volume of the molecules was estimated using Density Functional Theory and computations were performed using the ORCA program [32a]. All the molecular structures were optimized using B3LYP functional hybrid and 6-311G $(\mathrm{d}, \mathrm{p})$ basis set. The visualization of optimized structure was performed using Vega ZZ software [32b], to obtain the 
information of volume. The van der Waals volume of acetone is $64.3 \AA^{3}$ while the van der Waals volume of methanol and acetonitrile is $36.9 \AA^{3}$ and $45.2 \AA^{3}$, respectively [32b]. The low removal ratio of tetrahydrofuran was related to its relatively large volume of $77.4 \AA^{3}$ and considering the van der Waals modeling with a $100 \%$ radius relativity [32b].

\section{Conclusions}

Further to the synthesis of 1, there are two methanol molecules encapsulated by each void within 1 and thus it became interesting to study the organic molecules removal in organic wastewater using 1 . Based on the experimental results, 1 has an ability to capture methanol, acetone, acetonitrile, and tetrahydrofuran with the removal ratios of $29.17 \%, 63.22 \%, 42.77 \%$, and $21.24 \%$, respectively. The findings of this research work can help towards the purification of organic waste water.

\section{Declarations}

\section{Funding}

This research did not receive any specific grant from funding agencies in the public, commercial, or notfor-profit sectors.

\section{Conflicts of interest/Competing interests}

The authors have no conflicts of interest to declare that are relevant to the content of this article.

\section{Availability of data and material}

All data generated or analyzed during this study are included in this published article [and its supplementary information files].

\section{Code availability}

Not applicable.

\section{Authors' contributions}

M. K. conceived and supervised this research. B. O. A. F. carried out the experiment and analyses, drafted and refined the manuscript. P. R. calculated size of neopentyl alcohol, methanol, acetone, acetonitrile, and tetrahydrofuran using ORCA [32a] and VEGA ZZ [32b] software. M. I. E, L. R, and P. R. refined the manuscript.

\section{Ethics approval}

Not applicable. 


\section{Consent to participate}

Confirm.

\section{Consent for publication}

Confirm.

Acknowledgements

The first author thanks M. K. of Shizuoka University for providing the opportunity to conduct the research and providing the laboratory facilities to conduct the measurement. The first author thanks P. R. of Computational Chemistry Group, Department of Chemistry, Faculty of Science, University of Mauritius for his support in calculating the size of neopentyl alcohol, methanol, acetone, acetonitrile, and tetrahydrofuran using ORCA [32a] and VEGA ZZ [32b] software. The first author also thanks M. I. E., L. R., and P. R. for refining the manuscript.

\section{Notes}

‡ Crystal data for 1 : formula $=\mathrm{C}_{42} \mathrm{H}_{56} \mathrm{CoN}_{10} \mathrm{O}_{4} \mathrm{~S}_{2}, \mathrm{M}=888.01$, lattice = 'monoclinic', $\mathrm{a}=$ 9.9613(3) $\AA$, $\mathrm{b}=$ 23.9517(5) $\AA, c=10.2582(3) \AA, a=90^{\circ} \beta=113.963(4)^{\circ}, Y=90^{\circ}, V=2236.55(12) \AA^{3}$, space group = P21/c $($ No. 14$), Z=2, \rho($ calcd $)=1.319 \mathrm{~g} \mathrm{~cm}^{-3}, \mu($ MoKa $)=0.529 \mathrm{~mm}^{-1}$, radiateon $=0.71073(\lambda, \AA)$, temp $=173.15$ $K$, reflns collected $=6126$, unique reflns $=5340$, param refined $=273, R 1[I>2 \sigma(I)]=0.0556$, wR2 [all data] $=0.1672, \mathrm{GOF}=1.064$. CCDC-2121123 contains the supplementary crystallographic data for this work and can be obtained through www.ccdc.cam.ac.uk/data_request/cif.

\section{References}

1. M. Khalifa, S. Bidaisee, The importance of clean water. Sch J Appl Sci Res 1(7), 17-20 (2018)

2. U.N. Desa (2016). Transforming our world: The 2030 agenda for sustainable development

3. M. Haseena, M.F. Malik, A. Javed, S. Arshad, N. Asif, S. Zulfiqar, J. Hanif, Water pollution and human health. Environmental Risk Assessment and Remediation 1(3), 16-19 (2017)

4. J.O. Ighalo, A.G. Adeniyi, J.A. Adeniran, S. Ogunniyi, A systematic literature analysis of the nature and regional distribution of water pollution sources in Nigeria. J. Clean. Prod. 283, 124566 (2021). https://doi.org/10.1016/j.jclepro.2020.124566

5. J. Mateo-Sagasta, S.M. Zadeh, H. Turral, J. Burke, Water pollution from agriculture: a global review (Executive summary, 2017)

6. D. Pan, J. Tang, The effects of heterogeneous environmental regulations on water pollution control: Quasi-natural experimental evidence from China. Science of The Total Environment 751, 141550 (2021). https://doi.org/10.1016/j.scitotenv.2020.141550 
7. A. Srivastava, B. Gupta, A. Majumder, A.K. Gupta, S.K. Nimbhorkar (2021). A comprehensive review on the synthesis, performance, modifications, and regeneration of activated carbon for the adsorptive removal of various water pollutants. Journal of Environmental Chemical Engineering, 106177. https://doi.org/10.1016/j.jece.2021.106177

8. I. Basturk, G. Varank, S. Murat-Hocaoglu, S. Yazici-Guvenc, E. Can-Güven, E.E. Oktem-Olgun, O. Canli, Simultaneous degradation of cephalexin, ciprofloxacin, and clarithromycin from medical laboratory wastewater by electro-Fenton process. Journal of Environmental Chemical Engineering 9(1), 104666 (2021). https://doi.org/10.1016/j.jece.2020.104666

9. R. Gulde, M. Rutsch, B. Clerc, J.E. Schollée, U. von Gunten, C.S. McArdell, Formation of transformation products during ozonation of secondary wastewater effluent and their fate in post-treatment: From laboratory-to full-scale. Water Res. 200, 117200 (2021). https://doi.org/10.1016/j.watres.2021.117200

10. M.H. Huang, Y.M. Li, G.W. Gu, Chemical composition of organic matters in domestic wastewater. Desalination 262(1-3), 36-42 (2010). https://doi.org/10.1016/j.desal.2010.05.037

11. E. Morgenroth, R. Kommedal, P. Harremoës, Processes and modeling of hydrolysis of particulate organic matter in aerobic wastewater treatment-a review. Water Sci. Technol. 45(6), 25-40 (2002). https://doi.org/10.2166/wst.2002.0091

12. Y.N. Liu, N. Liu, R. Qu, W. Zhang, Y. Wei, L. Feng, PG-PEI-Ag NPs-Decorated Membrane for Pretreatment of Laboratory Wastewater: Simultaneous Removal of Water-Insoluble Organic Solvents and Water-Soluble Anionic Organic Pollutants. Langmuir 35(24), 7680-7690 (2019). https://doi.org/10.1021/acs.langmuir.9b00515

13. N. Chaukura, W. Moyo, B.B. Mamba, T.I. Nkambule, Removal of dissolved organic matter from raw water using zero valent iron-carbonaceous conjugated microporous polymer nanocomposites. Physics and Chemistry of the Earth, Parts A/B/C 107, 38-44 (2018). https://doi.org/10.1016/j.pce.2018.08.006

14. T. Wang, H. Liang, L. Bai, X. Zhu, Z. Gan, J. Xing, G. Li, T.M. Aminabhavi, Adsorption behavior of powdered activated carbon to control capacitive deionization fouling of organic matter. Chem. Eng. J. 384, 123277 (2020). https://doi.org/10.1016/j.cej.2019.123277

15. Y. Hu, C. Chen, L. Yang, J. Cui, Q. Hao, D. Sun, Handy purifier based on bacterial cellulose and Camontmorillonite composites for efficient removal of dyes and antibiotics. Carbohydrate polymers 222, 115017 (2019). https://doi.org/10.1016/j.carbpol.2019.115017

16. T. Wang, Z. Cheng, Y. Liu, W. Tang, T. Fang, B. Xing, Mechanistic understanding of highly selective adsorption of bisphenols on microporous-dominated nitrogen-doped framework carbon. Science of The Total Environment 762, 143115 (2021). https://doi.org/10.1016/j.scitotenv.2020.143115

17. K. Gupta, O.P. Khatri, Fast and efficient adsorptive removal of organic dyes and active pharmaceutical ingredient by microporous carbon: Effect of molecular size and charge. Chem. Eng. J. 378, 122218 (2019). https://doi.org/10.1016/j.cej.2019.122218 
18. B. Wang, Q. Zhang, G. Xiong, F. Ding, Y. He, B. Ren, L. You, X. Fan, C. Hardacre, Y. Sun, Bakelite-type anionic microporous organic polymers with high capacity for selective adsorption of cationic dyes from water. Chem. Eng. J. 366, 404-414 (2019). https://doi.org/10.1016/j.cej.2019.02.089

19. G. Cai, P. Yan, L. Zhang, H.C. Zhou, H.L. Jiang, Metal-organic framework-based hierarchically porous materials: Synthesis and applications. Chem. Rev. 121(20), 12278-12326 (2021). https://doi.org/10.1021/acs.chemrev.1c00243

20. K. Biradha, A. Ramanan, J.J. Vittal, Coordination polymers versus metal- organic frameworks. Crystal Growth and Design 9(7), 2969-2970 (2009). https://doi.org/10.1021/cg801381p

21. A.Y. Robin, K.M. Fromm, Coordination polymer networks with O-and N-donors: What they are, why and how they are made. Coord. Chem. Rev. 250(15-16), 2127-2157 (2006).

https://doi.org/10.1016/j.ccr.2006.02.013

22. A. Gallego, C. Hermosa, O. Castillo, I. Berlanga, C.J. Gómez-García, E. Mateo-Martí, Martínez, J. I., Flores, F., Gómez-Navarro, C., Gómez-Herrero, J., Delgado, S., \& Zamora, F. (2013). Solvent-Induced Delamination of a Multifunctional Two Dimensional Coordination Polymer. Adv. Mater., 25(15), 2141-2146. https://doi.org/10.1002/adma.201204676

23. N. Contreras-Pereda, P. Hayati, S. Suárez-García, L. Esrafili, P. Retailleau, S. Benmansour, F. Novio, A. Morsali, D. Ruiz-Molina, Delamination of 2D coordination polymers: The role of solvent and ultrasound. Ultrason. Sonochem. 55, 186-195 (2019).

https://doi.org/10.1016/j.ultsonch.2019.02.014

24. B.O.A. Fauzi, M. Kondo, Syntheses of Novel Coordination Polymers Using Bis-Imidazole Ligand Having Steric Hindrance and Methoxy Group. Online Journal of Chemistry 1(1), 29-37 (2021). https://doi.org/10.31586/ojc.2021.010104

25. M. Mochizuki, T. Inoue, K. Yamanishi, S. Koike, M. Kondo, L. Zhang, H. Aoki, Efficient removal of perchlorate ion from water by a water-insoluble M 2 L 4 type compound. Dalton Trans. 43(48), 17924-17927 (2014). https://doi.org/10.1039/C4DT02900C

26. A. Murakami, K. Yamanishi, E. Sone, M. Kondo, Preferential removal of perchlorate ion from water using self-assembled constructions of cationic 3D coordination frameworks with methylene units. Chem. Lett. 44(7), 1007-1009 (2015). https://doi.org/10.1246/cl.150316

27. E. Sone, M. Sato, M. Mochizuki, C. Kamio, K. Yamanishi, M. Kondo, Cationic M 2 L 4 cages for perchlorate removal from aqueous solutions and preferential perchlorate incorporation in hydrophilic solutions. CrystEngComm 18(26), 5004-5011 (2016). https://doi.org/10.1039/C6CE00267F

28. A. Kheddo, L. Rhyman, M.I. Elzagheid, P. Jeetah, P. Ramasami, Adsorption of synthetic dyed wastewater using activated carbon from rice husk. SN Applied Sciences 2(12), 1-14 (2020). https://doi.org/10.1007/s42452-020-03922-5

29. E.H. Umukoro, M.G. Peleyeju, A.O. Idris, J.C. Ngila, N. Mabuba, L. Rhyman, P. Ramasami, O.A. Arotiba, Photoelectrocatalytic application of palladium decorated zinc oxide-expanded graphite electrode for the removal of 4-nitrophenol: experimental and computational studies. RSC Adv. 8(19), 1025510266 (2018). https://doi.org/10.1039/C8RA00180D 
30. S. Vivekanandam, V. Muthunarayanan, S. Muniraj, L. Rhyman, I.A. Alswaidan, P. Ramasami, Ingenious bioorganic adsorbents for the removal of distillery based pigment-melanoidin: preparation and adsorption mechanism. Journal of Macromolecular Science, Part A 56(1), 52-62 (2019). https://doi.org/10.1080/10601325.2018.1527180

31. F. Malz, H. Jancke, Validation of quantitative NMR. J. Pharm. Biomed. Anal. 38(5), 813-823 (2005). https://doi.org/10.1016/j.jpba.2005.01.043

32. For the volume of molecules, Density Functional Theory (DFT) calculation was conducted using ORCA program ${ }^{\mathrm{a}}$. All of the molecular structures were optimized using B3LYP functional hybrid and 6$311 \mathrm{G}(\mathrm{d}, \mathrm{p})$ basis set. The visualization of optimized structure was performed using Vega ZZ software, to obtain the information of volume ${ }^{b}$. a) Neese, F. (2018). Software update: the ORCA program system, version 4.0. Wiley Interdisciplinary Reviews: Computational Molecular Science, 8(1), e1327. https://doi.org/10.1002/wcms.1327 b) A. Pedretti, L. Villa, G. Vistoli (2004). VEGA-an open platform to develop chemo-bio-informatics applications, using plug-in architecture and script programming. Journal of computer-aided molecular design, 18(3), 167-173. https://doi.org/10.1023/B:JCAM.0000035186.90683.f2

\section{Figures}

a

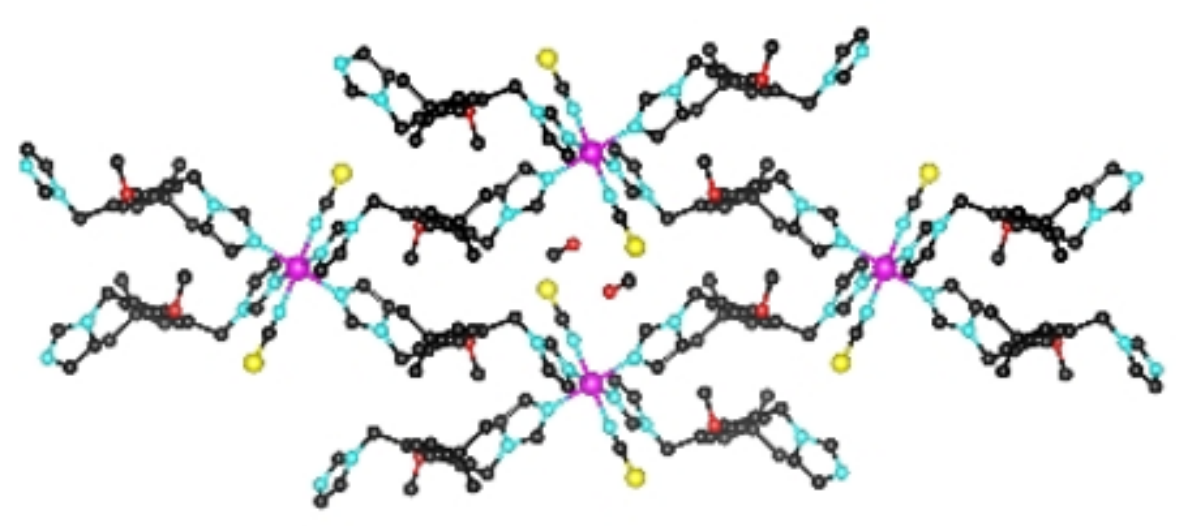

b

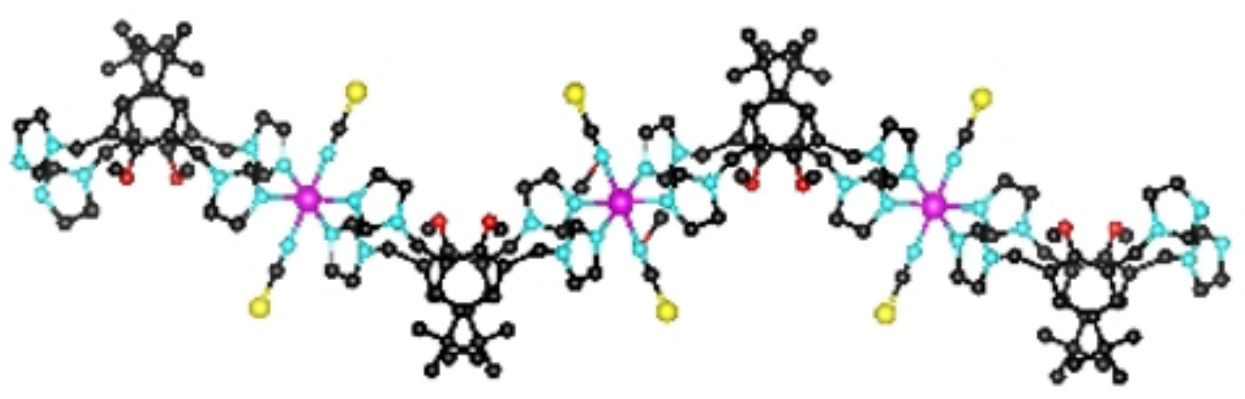

\section{Figure 1}

(a) Infinite structures of $\left\{\left[\mathrm{Co}(\text { bitbu-OMe })_{2}(\mathrm{NCS})_{2}\right] \cdot 2 \mathrm{MeOH}\right\}_{\mathrm{n}}$ viewed along a axis, (b) side view of $\left\{\left[\mathrm{Co}(\text { bitbu-OMe })_{2}(\mathrm{NCS})_{2}\right] \cdot 2 \mathrm{MeOH}\right\}_{\mathrm{n}}$. (Hydrogen atoms are omitted for clarity. Color code: magenta, cobalt; 
cyan, nitrogen; black, carbon; yellow, sulfur).

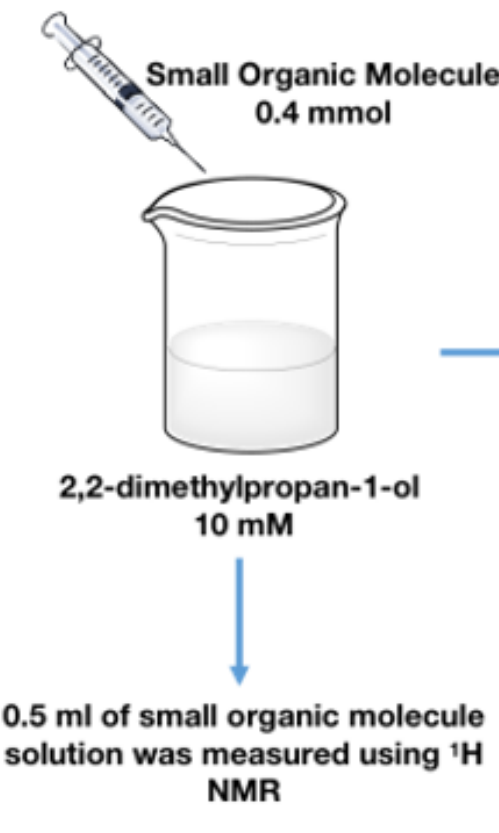

(Before Treatment)

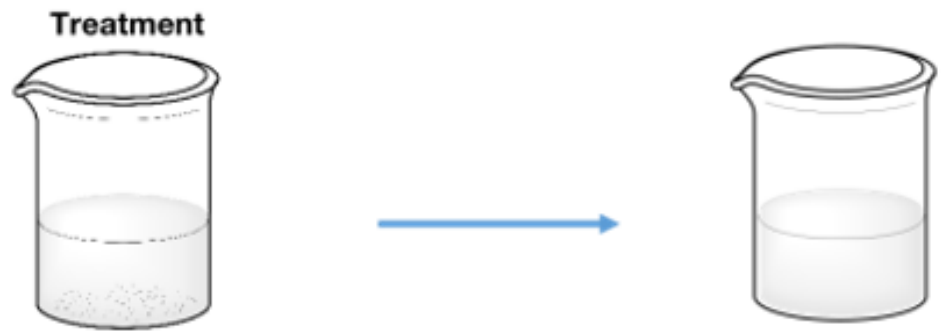

$0.04 \mathrm{~g}$ of $\left\{\left[\mathrm{Co}(\text { bitbu-OMe })_{2}(\mathrm{NCS})_{2}\right] \cdot 2 \mathrm{MeOH}\right\}_{n}$ heated powder was added into the solution.

The solution was stirred for $1 \mathrm{hr}$, RT
The mixture was filtered

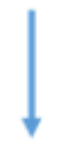

$0.5 \mathrm{ml}$ of small organic molecule solution was measured using ${ }^{1} \mathrm{H}$ NMR

(After Treatment)

\section{Figure 2}

The illustration of small organic matters removal in organic wastewater using desolvated 1 powder.

$+00$

$+00$

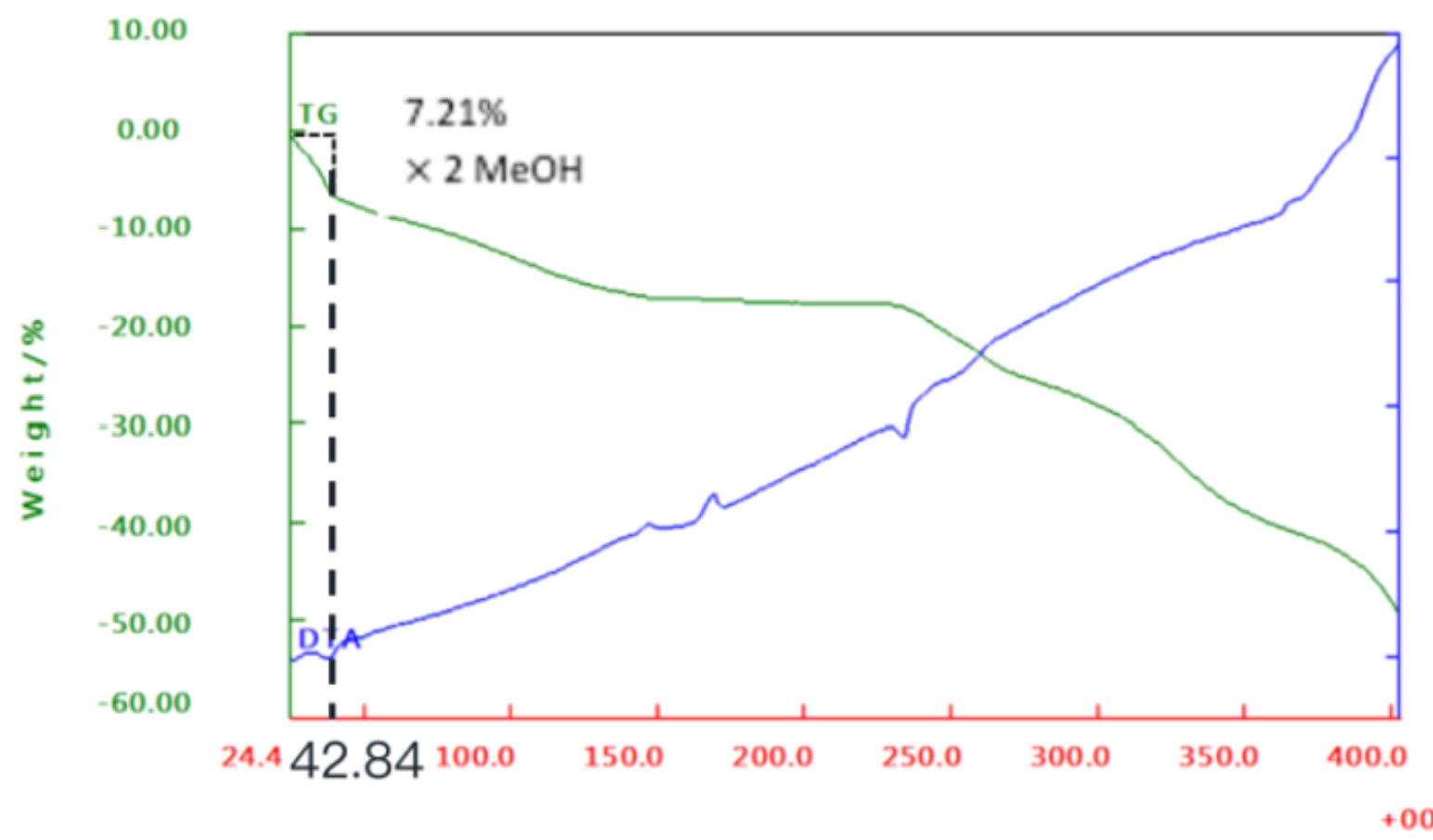

100.0

80.0

60.0

40.0

20.0

$>$
0
3
0
$\frac{1}{4}$
$\div$
0
0
1

Temperature $/{ }^{\circ} \mathrm{C}$ 
Figure 3

TG and DTA graph of 1 powder (TG result, green line; DTA result, blue line).

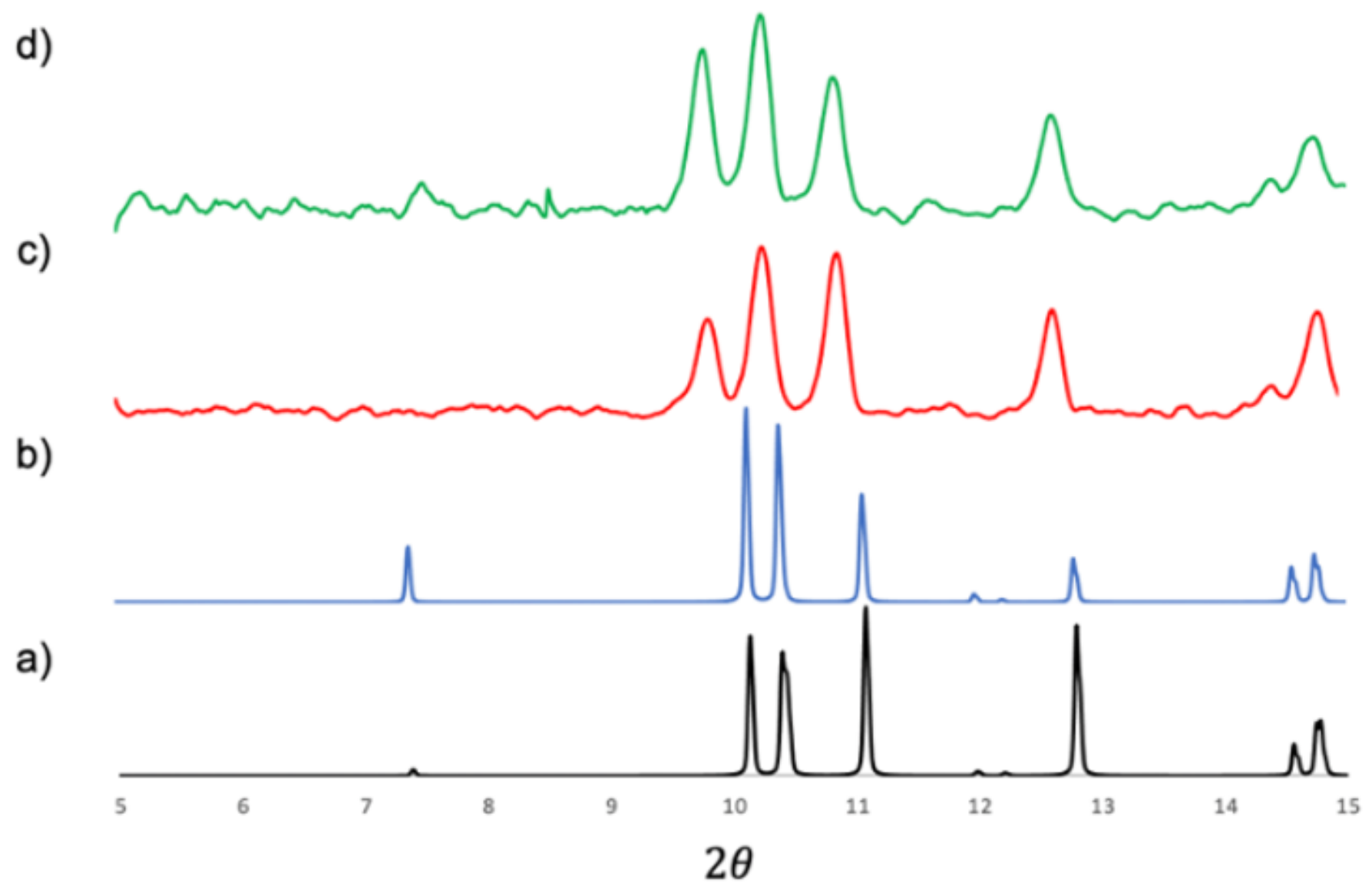

Figure 4

(a) The simulated PXRD pattern of 1 with $\mathrm{MeOH}$ guest molecule based on single crystal XRD data, (b) The simulated PXRD pattern of 1 without $\mathrm{MeOH}$ guest molecule based on single crystal XRD data, (c) the Observed PXRD pattern of 1 powder before heated, (d) the Observed PXRD pattern of 1 powder after heated at $45^{\circ} \mathrm{C}$. The patterns are shown in the range from $5^{\circ}$ to $15^{\circ}$. 
a

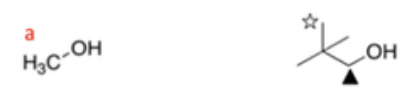

Before

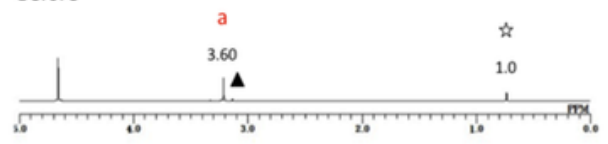

After

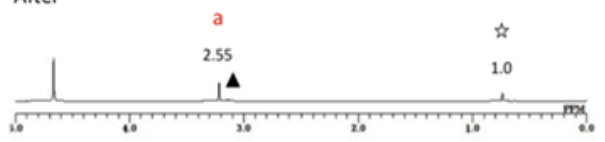

b
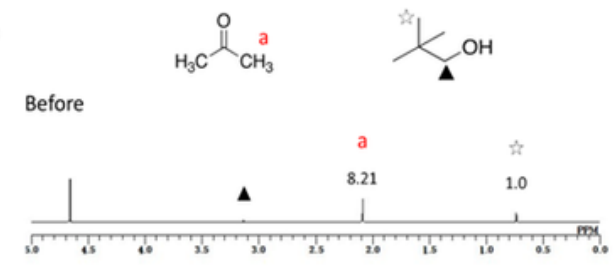

After

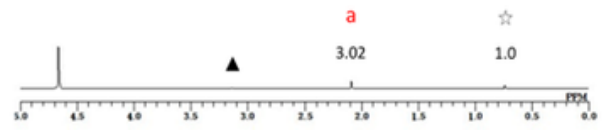

c
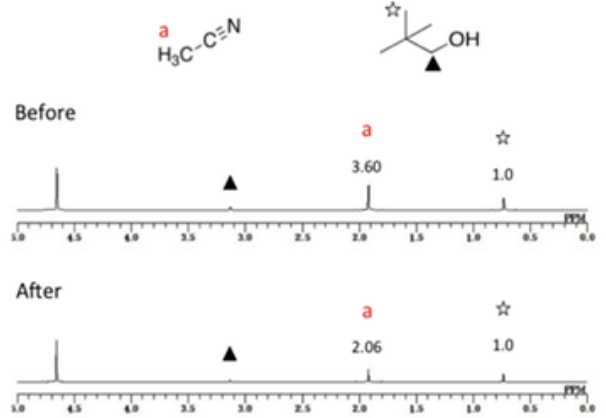

d
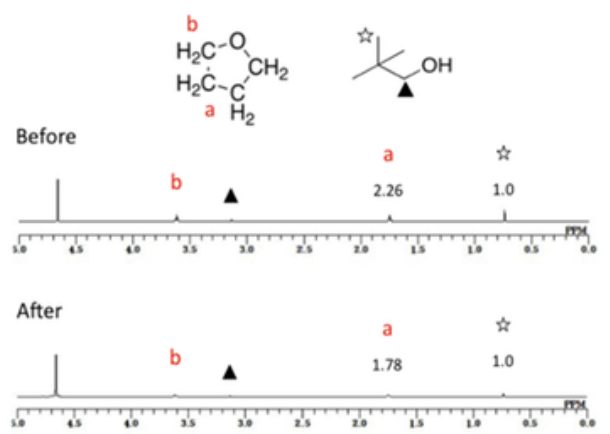

\section{Figure 5}

${ }^{1} \mathrm{H}$ NMR spectrum of (a) methanol, (b) acetone, (c) acetonitrile, and (d) tetrahydrofuran guest molecules before and after removal treatment using desolvated 1 powder. 